\title{
後腹膜腔鏡下リンパ節摘出法の改善 Improvement of lymphadenectomy in retroperitoneoscopy
}

石川県立中央病院 産婦人科

干場 勉、篠倉千早、高橋 仁、前川真知子、齋藤里奈 吉成秀夫、石川博士、平吹信弥、佐々木博正、朝本明弘

\section{はじめに}

後腹膜腔を内視鏡で見てリンパ節を摘出する方 法は1986年から試みられたとされ1)、我が国では 安藤らが最初に行い、多数例に実施してきている2)。 その方法は出血のない空間で、かつ低侵襲でリン パ節が徹底的に摘出できるというすばらしいもの である。しかし、安藤らのエンドチップカニュー レ（Karl Storz、以下Endotip）を用いた手技に は熟練者のみが行えるような難しい面が、また後 腹膜アプローチ法自体には以下のような問題点が 存在すると思われる。

1. Endotipなどを用いた腹膜剥離：

Endotipおよびそこからの鉗子での後腹膜剥離 は熟練が必要で、腹膜損傷の可能性がある。損傷 部位からガス漏れを生じると後腹膜腔が形成でき ず、最初の段階でつまずくことになる。

2 . 第 1 以後のトロッカーでの腹膜損傷 :

バルーンによる拡張などで後腹膜腔を拡張して も、腹膜が剥離されていないと腹壁と腹膜との間 に腹腔の空間が薄く存在する（図 1 ）。その部分 に特に抜けやすいトロッカーを挿入するとガスが 漏出する。バルーンでは拡張が大き過ぎると破裂 創を形成し、逆に小さいとトロッカー間が狭くな る。

3. 長時間操作によるトロッカー滑脱と創 :

リンパ節摘出とそれに続く悪性腫瘍手術では手 術時間が長く、長時間鉗子を動かす必要が生じる。 その場合トロッカーが抜けやすくなり、さらに時 間を要する原因となる。また、時間が長いとトロ ッカー創がきれいでなくなる。

4.トロッカー間の干渉 :

左側腹部に 4 本のトロッカーを設置するため、

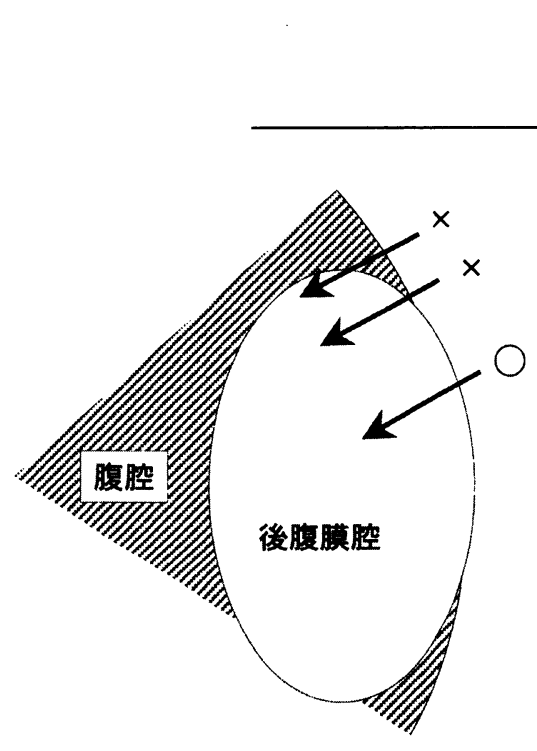

図1，後腹膜腔バルーン拡镸後のトロッカー害刺

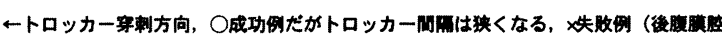

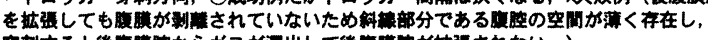

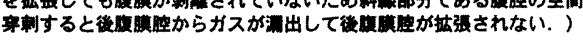

特に小柄な症例では鉗子やトロッカー同士が干渉 することがある。

そこで、今回、当院での施行症例から、比較的 簡単に後腹膜腔を展開できて、操作もやりやすく なると思われる方法を検討してみた。

\section{対象と方法}

対象は2000年 7 月から 2005 年 9 月までの後腹膜 腔でリンパ節摘出を行った 98 例である。これらの 症例の手術手技、手術続行の有無と、術式変更の 理由を検討した。

\section{成 績}

2000年 7 月から始めた 98 例の後腹膜腔のリンパ

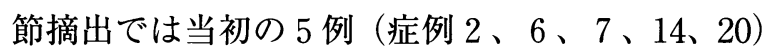
が腹腔鏡へ、40症例目が開腹に移行し、続行不能

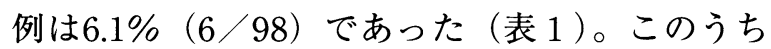
症例 $6 、 14$ では安藤らの用いているEndotipが、 
表 1 後腹膜腔鏡下手術続行不能例

\begin{tabular}{lllll}
\hline 原因 & 症例番号 & 対処 & 発生率 \\
\hline 腹膜損傷 & $2,6,7,14,20$ & 腹腔鏡下手術 & $5.1 \%$ \\
気胸 & 40 & & 開腹手術 & $1.0 \%$ \\
\hline
\end{tabular}

症例 $2 、 7 、 20 、 40$ では腹膜外腔拡張バルーンシ ステム PDBバルーン (キドニー型)（tyco、以下 PDB）が用いられていた。

続行不能例のうちの腹膜損傷では後腹膜腔の上 下内側の全域で腹膜損傷が見られた（図 2 )。こ の原因を分析すると、Endotipを用いたものでは 後腹膜腔内側にEndotipの先端やEndotipから出 した腹膜剥離のための鉗子による剥離が強過ぎて 小さな損傷を生じていた（表 2 ）。しかし、PDB を用いた場合でも拡張前のバルーン先端での剥離 やバルーンの過㮃拡張による大きな損傷が観察さ れた。さらには後腹膜腔への第 2 トロッカー拥入 時の腹腔貫通による腹膜損傷がみられた。

なお、症例40は55歳で問題なく後腹膜腔にトロ ッカー設置終了直後に左胸郭に気胸が発生し、胸 腔ドレーンを挿入した後に開腹移行した。また、 症例 51 は 43 歳で気腹開始から 2 時間後の後腹膜操 作終了時点で軽度の気胸が疑われたが、無処置で 予定の開腹操作に移行し、手術終了時点で気胸は 消失していた。

前述の問題点に対しては次のような対応がなさ

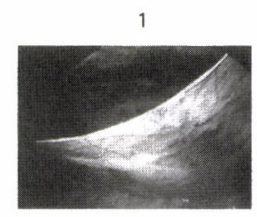

2
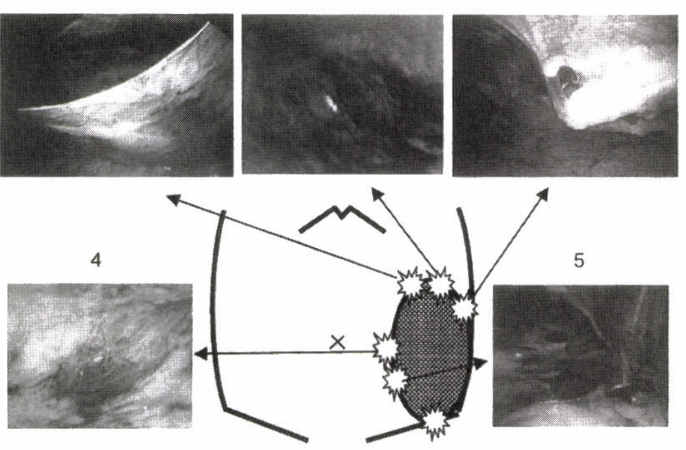

図 2. 腹膜破損部位とその状態

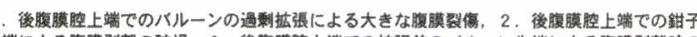

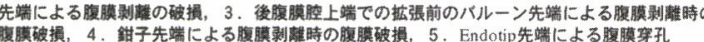

表 2 腹膜損傷の原因

1. Endotip先端

2 、鉗子先端による腹膜剥離

3 。拡張前のバルーン先端による腹膜剥離

4. バルーンの過剩拡張

5 . 後腹膜腔辺縁でのトロッカー貫通
れていた。すなわち、Endotipやその後の鉗子に よる剥離での腹膜損傷に対してはPDBを用い、 また、バルーンによる損傷に対しては剥離を最小 限として拡張も控えめにすることにより腹膜損傷 症例は減少し、さらに修復することで腹腔鏡への 移行は症例 20 以後無くなった。また、step single-use systemトロッカー（tyco、以下step） を使用することにより仮に腹膜を貫通してもガス 漏れが見られず、比較的安心してトロッカー穿刺 を行うことができるようになった（図３）。さら に長時間操作ではバルーン付トロッカーであるブ ラントチップトラカール（tyco、以下BTT）や stepを使用すると抜けにくく、BTTでは創もき れいとなった。 $2 \mathrm{~mm}$ トロッカーであるミニポー ト（tyco）は傷が小さくトロッカー間の干渉が少 なくなった。

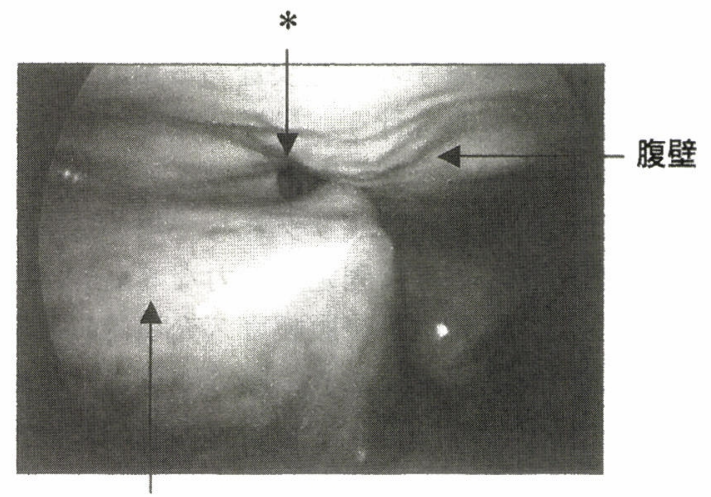

後腹膜

図 3,stepの腹腔内腔貫通例

* stepのダイレータカニューレが腹腔内を通り後腹膜腔に達し ているが手術は通常通り行われた。

以上の改善により最後の10症例の腹腔内観察終 了時点から後腹膜腔操作用トロッカー設置までの 所要時間は $12.8 \pm 2.5$ 分となっていた。また、最新 の手術手技は以下の通りとなっていた（図 4、表 3 )。

1. 臍からの光学視管装着可能な $5 \mathrm{~mm}$ トロッカ 一を用いて鏡視下に腹腔内に入り腹腔を観察す

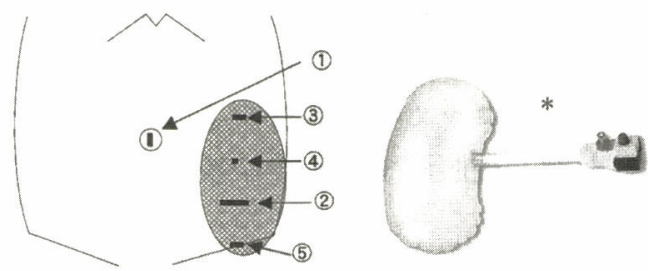

図 4. 後腹膜腔形成に用いるトロッカーと部位

*腹膜外腔拡張バルーンシステ

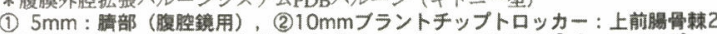
横指内側(PDB * で後腹膜拡張後)，(3) $5 \mathrm{~mm}$ step : 季助下, (4) $2 \mathrm{~mm}$ ミニホホー ト: (2)と(3)の間，(5) $5 \mathrm{~mm}$ step : 鼠徍部 
1. 臍に $5 \mathrm{~mm}$ トロッカーを挿入し $15 \mathrm{mmHg}$ で腹腔鏡を開始

2. 上前腸骨棘 2 横指内側を $15 \mathrm{~mm}$ 切開し後腹膜まで剥離

3. 腹腔鏡観察下にPDBバルーンを側腹部に挿入

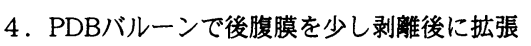

5. $\mathrm{PDB}$ バルーン抜去後 $10 \mathrm{~mm}$ ブラントチップトロッカーを装着

6. $5 \mathrm{~mm}$ トロッカー（step）を後腹膜腔上端に扱入

7. $2 \mathrm{~mm}$ ミニポートをstepとブラントチップトロッカー間に挿入

8. $5 \mathrm{~mm}$ トロッカー（step）を後腹膜腔下端に挿入

9. 気腹圧を $8 \mathrm{mmHg}$ に下げて操作を開始

る。

2 .上前腸骨棘より 2 横指内側に $1.5 \mathrm{~cm}$ の切開を 加え、腹膜まで剥離後キシロカインゼリーを少量 塗布したPDBを挿入し、腹膜と筋膜との間を腹 膜損傷しないように少し剥離する。つぎにインフ レーションポンプを用いてバルーンを拡張させ、 腹腔鏡で見て希望の部位近くまでやや控えめに後 腹膜腔を展開する。その後バルーンを抜去し、 $10 \mathrm{mmBTT}$ 装着する。必要なら $5 \mathrm{~mm}$ 光学視管 で後腹膜腔の展開を行う。視野確保は主にこのト ロッカーから $10 \mathrm{~mm}$ 光学視管で行う。拡張後のバ ルーンは切除後に回収バッグとして用いる。

3 . 左季肋下に組織の固定が強力な $5 \mathrm{~mm}$ stepを 装着するが、腹腔鏡で後腹膜ガス充填時に腸管の 瘉着が無いか確認しておき、腸管が無ければ躊躇 することなく腹腔を貫いても希望の場所に設置す る。

4. 2 と 3 のトロッカーの間にミニポートを挿入 する。

5. 左鼠径部に $5 \mathrm{~mm}$ stepを挿入する。

6. 設置後は気腹圧を15から $8 \mathrm{mmHg}$ にだて リンパ節郭清を傍大動脈と骨盤領域で行う。もし、 後腹膜の漏れが生じた場合は縫合やセプラフィル 么貼付で対処する。

\section{考察}

後腹膜腔でのリンパ節摘出は腹腔内に入ること なく行えるので、腹膜が自然のテントとなり手術 が行いやすい。また、腹腔鏡では骨盤高位とした り、他のトロッカーで腸管をよけたりする作業が 必要だが、後腹膜ではその必要がなく非常に良い 方法である。

後腹膜鏡下手術は後腹膜臓器を扱う泌尿器科で よく行われてきており、1979年に尿管結石の手術 をWickhamが紹介している ${ }^{3)}$ 。その後1992年に Gaurがバルーンを用いて腔を展開する侵襲の少 ない方法を報告した ${ }^{4)}$ 。これ以後この方法は広く 用いられるようになり、やがてバルーンのついた
トロッカーが登場した5)。婦人科領域でもV V asilev らがバルーンを用いた方法で良好なリンパ節郭清 の成績を報告している ${ }^{6)}$ 。

安藤らの後腹膜形成方法はEndotipの性質を応 用した安価で実に効果的な方法であるが、初心者 には後腹膜剥離の加減に難しい面があり、当院で も最初ある程度慣れるまで失敗例が発生してい た。ところが、PDBを用いて拡張を適度に行う ことで腹腔鏡移行症例はほとんど無くなった。こ れはおそらく全体的に後腹膜をはがしていくため に、一部に力が加わって傷を作ることが無いため であろう。ただ、PDBの欠点は定価約 2 万 5 千 円と高価なことである。

しかし、バルーンでも強く剥離したり過剩に膨 らませしたりすると炎症のあった弱い部位は破綻 することがあるので、拡張は必要最低限とすべき である。Gaurもバルーンの破損の問題や炎症部 位があった場合での静脈や周辺臓器、腹膜などの 組織損傷を報告しており、侵襲が少ない方法とは 言え注意が必要であろう7)。ただ、この方法を用 いれば手術の最も難しいところのひとつが比較的 初心者でも行えるという大きな鬼力があると思わ れる。

次にBTTはバルーンとスポンジで皮膚を挟み 込む形となっている。このトロッカーを用いると 皮膚への固定がよく、かなり動かしても丈夫であ る。また、手術全体は 4 〜 時間の長さに及んだ が、傷は単なる筒状のトロッカーを装着した場合 と比較すると、非常にきれいな状態となった。こ れは皮膚への無理な圧迫が無いためと思われる が、同じような機能をもつトロッカーを用いても 同様の結果を得られると考えられる。Gillも後腹 膜鏡を行う上で大切な技術として、バルーントロ ッカーの他にブラントチップトロッカーを挙げ、 気腹を保ち、皮下気腫を最小限にするのに重要な ものであると指摘している

また、トロッカー配置では極力間隔を取ろうと すると腹膜剥離やトロッカー設置時に腹膜が損傷 するわけだが、それを回避するために腹膜の剥離 にswab stickを用いたり、試験穿刺を行ったりす る方法も報告されている 程度腹膜を貫通するような、できれば回避したい 状況でも抜けにくいことから、十分な腹膜剥離が なされていない時もガス漏れが少なく比較的安心 して設置できる点で有用と思われた。

またstepを用いる部位はかなり術中頻繁に、し かも大きな角度で動かす場所であるが、自然に抜 
けてくることは非常にまれであった。欠点として はやや值段が高いことがあげられるが、これも術 中抜けることによる煩雑さを考えれば妥当な選択 と思われる。

$2 \mathrm{~mm}$ 径のトロッカーではトロッカー間の干渉 が少なかった。また、摘出するリンパ節は大きな ものではないので、 $2 \mathrm{~mm}$ 径の鉗子でも十分把持 することが可能であったし、また、リンパ節自体 は極力周辺を把持して直接圧力を加えて潰さない ようにする面からも細い鉗子の方が有効かもしれ ない。 $2 \mathrm{~mm}$ 鉗子であるミニサイトエンドグラス プ（tyco）は意外に把持力が強く、また、 $2 \mathrm{~mm}$ の傷はほとんど目立たずきれいな状態となる。さ らに、傷が小さく、干渉が少ないので、必要であ ればさらに $2 \mathrm{~mm}$ トロッカーを追加することも行 いやすい。

Sungらは後腹膜鏡下手術において正しく後腹 膜腔を展開するうえで解剖学的な目印、特に腸腰 筋を明確にする重要性を伸べているが、バルーン や目印の使用、手術時間の解析によって手術時間 を $4 、 5$ 時間から $2 、 3$ 時間に短縮できたと報告

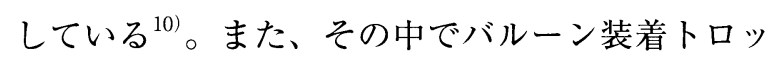
カーを用いて、3、4 本のトロッカーを設置する のに要する時間は $12 \pm 3.9$ 分としており、この所 要時間は現在の当院の状況によく似ていた。

なお、気胸症例が 2 例見られたが、とくに既往 歴や合併症のない比較的若い症例であったことか ら、老化に伴うものではなく、解剖学的な個体差 による可能性が考えられた。Wolfらは骨盤腔の 腹腔鏡手術でも $9 \%$ に気胸を時に伴う気縦隔がみ られたと報告している ${ }^{11)}$ 。その中で後腹膜アプロ 一チと皮下気腫、気腹時間の長さが各々高炭酸ガ ス血症に関連し、後腹膜法では気腹時間と皮下気 腫が強く影響したと述べている。したがって、あ る程度の気胸は生じている可能性があるが、顕在 化するに至っていないだけなのかもしれない。当 院では皮下気腫との関連は伺えなかったが、術中 は高い気腹圧を避けるようにし、高度の皮下気腫 や高炭酸ガス血症、急激な酸素飽和度の低下を慎 重に観察する必要はあろう。

以上の工夫を用いることにより後腹膜腔への到 達とそこでの操作はより簡便なものとなると思わ れる。しかし、大血管周囲の手術であるので、損 傷時の応援体制がある状態で、あくまでも慎重に、 十分な解剖学的知識を持って望むことは必須と思 われた。

\section{文献}

1) Dargent D. : A new future for Schauta's operation through presurgical retroperitoneal pelvicoscopy. Eur J Gynaecol Oncol 8: 292-296, 1987.

2) 安藤正明, 他：婦人科悪性疾患に対する後腹膜り ンパ節郭清. 産婦人科治療, $89: 455-463,2004$.

3 ) Wickham JEA. : The surgical treatment of renal lithiasis. In Urinary Calculous Desease (ed. Wickham JEA), pp145-198. Churchill-Livingstone, New York, 1979.

4) Gaur DD. : Laparoscopic operative retroperitoneoscopy: use of a new device. J Urol 148:11371139, 1992.

5 ) Hirsch IH, et al. : Controlled balloon dilatation of the extraperitoneal space for laparoscopic urologic surgery. J Laparoendosc Surg 4:247-251, 1994.

6) Vasilev SA, McGonigle KF. : Extraperitoneal laparoscopic para-aortic lymph node dissection. Gynecol Oncol 61: 315-320. 1996.

7 ) Gaur DD, et al.: A single-centre experience of retroperitoneoscopy using the balloon technique. BJU Int 87: 602-606, 2001.

8 ) Gill IS, Rassweiler JJ. : Retroperitoneoscopic renal surgery: our approach. Urology 54:734-738. 1999.

9) Wakabayashi Y, et al. : Simple techniques for atraumatic peritoneal dissection from the abdominal wall and for preventing peritoneal injury during trocar placement under retroperitoneoscopy. J Urol 169: 256-257, 2003.

10) Sung GT, Gill IS. : Anatomic landmarks and time management during retroperitoneoscopic radical nephrectomy. J Endourol 16: 165-169, 2002.

11) Wolf JS Jr, et al. : Carbon dioxide absorption during laparoscopic pelvic operation. J Am Coll Surg 180:555-560. 1995. 